DOI: 10.47750/jett.2021.12.01.014

\title{
Post-revolution oriental studies in the ussr: correspondence between v. V. Bartold and a. Y. Krymsky in the 1920s
}

R.M. Valeev ${ }^{1}$

R.Z. Valeeva ${ }^{2}$

O.D. Vasylyuk ${ }^{3}$

D. R. Khayrutdinov ${ }^{4}$

S. A. Kirillina ${ }^{5}$

\section{Journal for Educators, Teachers and Trainers, Vol. 12 (1)}

\section{https://jett.labosfor.com/}

Date of reception: 07 October 2020

Date of revision: 05 January 2021

Date of acceptance: 03 April 2021

R.M. Valeev, R.Z. Valeeva, O. D. Vasylyuk, D. R. Khayrutdinov, S. A. Kirillina (2021). Post-revolution oriental studies in the ussr: correspondence between v. V. Bartold and a. Y. Krymsky in the $1920 \mathrm{~s}$. Journal for Educators, Teachers and Trainers, Vol. 12(1). 104 - 116.

${ }^{1}$ Doctor of Sciences (History), Professor of the Department of Altaic and Chinese studies, Institute of International Relations, Kazan (Volga Region) Federal University

${ }^{2} \mathrm{Ph} . \mathrm{D}$ (Pedagogics), Associate Professor, Head of Department at Kazan Innovative University named after V.G. Timiryasov (IEML).

${ }^{3} \mathrm{Ph} . \mathrm{D}$ (History), Senior Fellow of A. Krymsky Institute of Oriental Studies, National Academy of Sciences of Ukraine

${ }^{4}$ Ph.D., Assistant Professor, Kazan Innovative University named after V.G. Timiryasov (IEML).

${ }^{5}$ Doctor of Sciences (History), Professor, Head of the Department of Middle and Near East History, Institute of Asian and African Studies, Lomonosov Moscow State University 


\section{Post-revolution oriental studies in the ussr: correspondence between v. V. Bartold and a. Y. Krymsky in the 1920s \\ R.M. Valeev ${ }^{1}$, R.Z. Valeeva ${ }^{2}$, O.D. Vasylyuk ${ }^{3}$, D. R. Khayrutdinov ${ }^{4}$, S. A. Kirillina ${ }^{5}$}

${ }^{1}$ Doctor of Sciences (History), Professor of the Department of Altaic and Chinese studies, Institute of International Relations, Kazan (Volga Region) Federal University

${ }^{2}$ Ph.D (Pedagogics), Associate Professor, Head of Department at Kazan Innovative University named after V.G. Timiryasov (IEML).

${ }^{3}$ Ph.D (History), Senior Fellow of A. Krymsky Institute of Oriental Studies, National Academy of Sciences of Ukraine

${ }^{4}$ Ph.D., Assistant Professor, Kazan Innovative University named after V.G. Timiryasov (IEML).

${ }^{5}$ Doctor of Sciences (History), Professor, Head of the Department of Middle and Near East History, Institute of Asian and African Studies, Lomonosov Moscow State University

Email ID: valeev200655@mail.ru

\section{ABSTRACT}

The primary reason for writing this article is a very special date - the 150th anniversary of the birth of academician and Orientalist V. V. Bartold, an event celebrated in Russia in 2019. At the turn of the twentieth century the scholar and humanist wrote: "Under the influence of the Golden East, Wonderland works written by European orientalists, the East of One Thousand and One Nights gradually retreats into the realm of legends; instead, the picture of the actual life of the Eastern peoples unfolds before us, and we find out the reasons that determined the course of their history and their role in the history of humankind. ${ }^{1}$ " Famous intellectuals and thinkers V. V. Bartold (1869-1930) and A.Y. Krymsky (1871-1942) and their legacy vividly showcase the earthly fate, scientific achievements and spiritual experience of the history of classical Oriental studies in Russia and Europe.

The collections of the Institute of Manuscripts of the V.I. Vernadsky National Library of Ukraine hold 10 letters written by V.V. Bartold addressed to A.Y. Krymsky, while the St. Petersburg Archive of the Russian Academy of Sciences keeps seven response letters from A.Y. Krymsky. Although the extant correspondence covers a period of twenty years, from 1908 to 1928, this article will focus on the significance of letters dating from the 1920s. The legacy of A.Y. Krymsky and V. V. Bartold has great historical, scientific and cultural weight in the history of Russian, Ukrainian, and European Oriental studies.

The article analyzes the unpublished correspondence between V.V. Bartold and A.Y. Krymsky between 1922 and 1928. It contains valuable data which helps reconstruct the main trends of contemporary academic life and improve understanding of existing problems in the field of Oriental studies in Russia in the 1920s. The correspondence of these distinguished scholars showcases their common professional interest in both the state of Oriental studies and the educational system.

Keywords: Russia, Ukraine, East, Oriental studies, epistolary legacy, the Islamic world.

\section{INTRODUCTION}

In 2017 the Department of Oriental Languages of Kazan Federal? University celebrated its 210th anniversary, while 2018 saw the 200th anniversary of the foundation of the Asiatic Museum (the Institute of Oriental Manuscripts of the Russian Academy of Sciences) and the Institute of Oriental Studies of the Russian Academy of Sciences. 2018 heralded 120 years from the beginning of A. Y. Krymsky's teaching work in Lazarev Institute of Oriental Languages in Moscow, while in 2021 Ukraine and Russia will celebrate the 150th birthday of A. Y. Krymsky. 2019 marked 165 years since the foundation of the Faculty of Asian and African Studies of St. Petersburg State University and 120 years since the creation of the Oriental Institute in Vladivostok. From their very inception, the interaction and cooperation of these leading centers of Asian and African studies of Russia and Europe was organic, and influential in the history and culture of the peoples of Russia and the development of Oriental studies. In the chain of salient scholarly events of 2019 in Russia, the 150th anniversary of the birth 
of V. V. Bartold has acquired great significance due to his prominent position as founder of the historical school of Oriental studies.

Studies of Russian orientalists were known to have a wide regional, chronological and topical range. In many ways, the local and international influence of Russian Oriental studies began to grow in tandem with the studies of classical and modern disciplines. Russian Oriental studies helped interpret and explore the greatness and tragedy of the history and culture of the various peoples of multiethnic and multi-religious Russia. Scholars honed in on the interaction between European and Asian historical and ideological symbols, as well as the geographical and historical-cultural interaction between Russia, the East and the West.

In the study of the phenomenon of oriental studies in Russia and the Soviet Union, special attention is paid to the epistolary legacy of Russian Orientalists. What is being conducted currently is the search, study, systematization, and publication of the correspondence of the prominent Arabist, Semitologist, Turkologist, Iranian scholar, and Slavist A. Y. Krymsky with prominent Orientalists V.R. Rosen, V.V. Bartold, P.K. Kokovtsov, F.E. Korsch, V.A. Zhukovsky, S.F. Oldenburg, I.Y. Krachkovsky, N.A. Mednikov, V.F. Minorsky and other scientists active during the period of the $1890 \mathrm{~s}-1930 \mathrm{~s}$.

\section{PROPOSED METHODOLOGY}

Our systematic methodology of addressing "documents of personal origin", namely the correspondence of eminent Russian Orientalists, is represented by a combination of four key research methods. In first place is the search, processing and expansion of the archival-epistolary base through comprehensive study of the personal collections of Orientalists in the archives of Russia and Ukraine (other countries may be added as necessary). In addition to correspondence, additional materials are consulted, including official documents, plans, and notebooks, among others. Following this first step is the search and systematization of bilateral correspondence (Krymsky - Rosen, Krymsky - Bartold, Krymsky - Minorsky, etc.). The third step encompasses the historiographic, source study-related and thematic search for and synthesis of historical and scientific facts and information presented in the correspondence. Once the synthesis is complete, the process is finalized with subsequent categorization and analysis to reach conclusions about the nature of the relations between the aforementioned academics and to establish the picture of scholarly life in the Russian Empire in the late $19^{\text {th }}$ and early $20^{\text {th }}$ centuries.

\section{RESULTS ANALYSIS}

The first decades in the history of Russian Oriental studies after the creation of the Soviet state were marked by significant scientific achievements, the beginning of the Soviet institutionalized system of education, and the development of fundamental and applied studies of the East, as well as a few tragic events that affected the fate of the academic community.

In this paper there is no need to delve too deep into the biographical milestones of famous Russian orientalists Vasily Vladimirovich Bartold (1869-1930) ${ }^{1}$ and Ahatanhel Yukhymovych Krymsky (1871-1942) ${ }^{2}$, because there is extensive modern historiography and an already formed source base. They belonged to the same generation and even had similar social and academic values but they had very different ethnic, social and cultural backgrounds. Both had excellent education and both ended up becoming outstanding scholars representing important centers of Oriental studies - St. Petersburg, Moscow and Kiev. Both did research in a broad variety of fields related to Arab and Islamic civilization. Both were elected academicians (V. V. Bartold became a member of the Russian Academy of Sciences in 1913, while A. Y. Krymsky - as a member of the Ukrainian Academy of Sciences in 1918).

In 1928 in a letter to academician I.Y. Krachkovsky A.Y. Krymsky noted: "However, a thought occurs to me: how did orientalists of St. Petersburg miss the anniversary of another scholar that is a treasure of Russian orientalism? I am talking about Bartold. It is clear that as soon as anyone raises an idea of publishing a collection of articles dedicated to him - the entire Europe will immediately respond, and this collection will come out no less impressive and valuable than, for instance, similar collections dedicated to Nöldeke, Browne, etc. $<>$ And it is clear that such a collection would be a worthy review of the old forces of orientalism and a collective document (alas, maybe the last of its sort) of something that is about to die and that the subsequent generation of orientalists will not be able to replace"3.

In 1941 academician I. Y. Krachkovsky, in highlighting the events dedicated to the 70th anniversary of the birth of Ukrainian academician A. Y. Krymsky, wrote the following: "It is a pleasure for our Academy to note that A. Krymsky from the early years of his work had a close-knit relationship with it. His relationship was preserved until his last years. ${ }^{4}$ " A.Y. Krymsky's personal and professional connections are in many ways organically related to academic Orientalists of the Petersburg center of Oriental studies. This is especially evident in the aforementioned "documents of personal origin" - the correspondence of V. V. Bartold and A. Y. Krymsky in the first decades of the 20th century.

The collection of academician V. V. Bartold in the St. Petersburg branch of the Russian Academy of Sciences Archive (fonds 68) includes letters to V. V. Bartold from scholars from various centers of the Russian Empire, 
the USSR and European correspondents from the late 1890 to 1920. Among them are some famous Russian Orientalists, such as V. M. Alekseev $(1881$ - 1951), E. E. Bertels $(1890$ - 1957), N. I. Veselovsky $(1848$ 1918), V. A. Zhukovsky (1858 - 1918), F. E. Korsch (1843 - 1915), I. Y. Krachkovsky (1883 - 1951), S.F. Oldenburg (1863 - 1934), A. Y. Krymsky, and some leading European scholars: E. Browne (1862 - 1926), H. Gibb (1895 - 1971), I. Goldziher (1850 - 1921), A. Müller (1848 - 1892), C. Snouck Hurgronje (1857 - 1936$)$, etc. $^{5}$

Letters from V.V. Bartold and A.Y. Krymsky - two participants in the tumultuous political and academic events of the 1920s - convey the spirit of the era and shed light on the sweeping changes in Asian and African studies in Russia during the first decade after the Revolution of 1917. Their pre-1917 letters are mainly devoted to the discussion of academic topics and issues of the study of the East, while their subsequent correspondence to a greater extent reflected upon socio-political and cultural problems and reflections.

The works and the legacy of the two outstanding orientalists of Russia of the late $19^{\text {th }}$ - first several decades of the $20^{\text {th }}$ centuries, and in particular the Soviet period, have showed the following trends: the development of Oriental studies in Russia/USSR becomes one of "the most important factors of the Russian culture", and a natural connection is established "between the development of Russian orientalism and the achievement of political and cultural goals of Russia in the East" (V. V. Bartold).

The nature and the areas of development of Oriental studies in USSR in the 1920s - 1930s were ambiguous and inconsistent. Revolutionary shifts in the society and science that occurred right after the October revolution of 1917 demanded a revision of the philosophical, theoretical, methodological and particularly organizational foundations of the Russian/Soviet Oriental science. These were the years when a radical change of institutional and scientific foundations of orientalism was taking place in Moscow, St. Petersburg, Kiev, Baku, Tashkent, Vladivostok and other academic and cultural centers of the USSR. At this time we witness the formation of academic Oriental studies based on the Marxist-Leninist methodology, new research subjects, as well as the new structure of scientific and educational institutions.

In 1920s - 1930s Oriental studies centers of Russia and the Soviet Union still had representatives of pre-USSR schools of orientalism working in them, but at the same time there was a new generation of Russian orientalists developing. Old journals and collections of academic papers on Oriental studies are being continued, in addition to the emergence of new ones. In the second half of the 1920s orientalism in the USSR begins experiencing the increasing ideological and political pressure. The dramatic and often tragic life events of Russian orientalists at that time are of particular interest.

The establishment of Soviet Oriental studies in the 1920 - 1930s was a complex and multi-faceted phenomenon. Its beginnings featured several "revolutionary" reorganizations and a renewal of Oriental science. The main Oriental studies center affiliated with the Academy of Sciences was still the Asiatic Museum. In 1921 the Asiatic Museum initiated the creation of the Board of Orientalists. It united professors and scholars from universities and academic centers of Petersburg. The Board of Orientalists published a journal called Zapiski Kollegii vostokovedov ("The Bulletin of the Board of Orientalists"), which was edited by V.V. Bartold. In the 1920s new Oriental research institutions were created in the Academy of Sciences, in addition to the Asiatic Museum and the Board of Orientalists: the Institute of Japhetic Languages (founded in 1921), the Institute of Buddhist Culture, the Turkology Office, etc. A permanent committee for the research of the tribal composition of the population of Russia was formed at the general assembly of the Academy of Sciences. The committee had four departments - the European Department, the Caucasus Department, the Siberian Department and the Turkestan Department - and existed from 1917 to 1929. It had its own printed platform - the Izvestiya newspaper. The new institute of the Soviet Oriental studies was the All-Russian Academic Association of Orientalists (AAAO, 1921). In 1921 - 1930 the Association published a journal called Novyi Vostok ("The New East"). In the 1920s besides AAAO there were other orientalism-related academic communities and committees as well. In 1922 a special Academic Oriental Committee was opened in Tashkent, affiliated to the Central Asia offices of the People's Commissariat for Foreign Affairs и the People's Commissariat for Foreign Trade. In 1925 a research group of orientalists was formed at the Communist University of the Toilers of the East (KUTV), and in 1927 this group was transformed into the Research Association of KUTV, etc. From 1927 onwards the primary theoretical and academic publication of KUTV was the Revolutsionnyi Vostok ("Revolutionary East") journal.

An important part in training of professionals for the Soviet policy in local communities was played by the Communist University of the Toilers of the East, founded in 1921.

Oriental studies at Soviet universities in Baku, Tashkent, Kiev, Tiflis, Kazan, Vladivostok and other cities was mostly centered around teaching Asian and African languages and doing research in geography, history, culture and ethnography.

The leading trend of this period is the reorganization of already existing Oriental educational institutions and the creation of new ones. One of them was the Moscow Institute of Oriental Studies. In September of 1920 V. I. Lenin signed the "Resolution on founding the Central Institute of Modern Oriental Languages" - CIMOL. This Institute was created on the basis of the Lazarev Institute of Oriental Languages. Famous Moscow arabist M.O. 
Attay was elected the director of CIMOL. In October of 1921 the Presidium of the All-Russian Central Executive Committee (VTsIK) adopted a resolution on the merging between CIMOL and the Oriental Department of Moscow University and the creation of a single united educational institution - the Institute of Oriental Studies.

The late 1920s and the 1930s mark the beginning of the Academy of Sciences reorganization. In 1929 a special government committee was conducting a thorough inspection of the Academy of Sciences, conducting checks on both its work and its members. In 1930 the Academy adopted its Charter, which stated that all academic work must serve the interests of the Soviet state. During the following years the work of the Academy was repeatedly discussed in the Central Committee of the Communist Party of the Soviet Union and the Council of People's Commissars (SNK). In 1934 it was passed under the supervision of SNK and transferred to Moscow. In 1935 a new Charter was adopted. The reorganization of the Academy also concerned the already existing institutions of Oriental studies - the Asiatic Museum, the Board of Orientalists, the Turkology Institute, the Institute of Buddhist Culture, etc. The main result of the reorganization was the formation of the Institute of Oriental Studies in the structure of the Academy of Sciences. Orientalist academic centers and researchers were mobilized to achieve the goals of Soviet state-building and culture-building.

The repressions of the 1920s - 1940s did enormous damage to the Russian/Soviet orientalism, took the lives of a lot of scholars, broke off the succession of studies, scientific schools and disciplines, including ones at universities. Academicians V. V. Bartold and A. Y. Krymsky also experienced political and ideological crises.

This was the dawn of an era of new institutions, new studies and new ideas in the history of Soviet orientalism, including academic disciplines and research fields focused on studying the East.

In 1923 Y.N. Rerikh wrote the following in his article "Orientalism": "Just a very short time ago orientalism was still a closed field where profound academic research was conducted, but whose treasures were not accessible for the rest of the world and were hidden behind a thick veil of time". He optimistically noted that "the new stage in orientalism is the total synthesis that would reflect the historical development of the Eastern countries in general while meeting the requirements of modern science".

The institutional model and the ideal of integrity and continuity of academic Oriental studies have taken final shape by the turn of the $20^{\text {th }}$ century. However this landmark point completely lost its dynamic during the early years of Soviet orientalism: the 1920s - 1940s.

The beginning of the correspondence of the Soviet period was marked by the relocation of A.Y. Krymsky in 1918 from Moscow to Kiev, where he was elected academician of the Ukrainian Academy of Sciences (UAS). Between 1918-1928 he forged his place as the indispensable Secretary of the Academy and became one of the founders of the national academic center. The first letters in which the scholars were able to exchange their thoughts and plans date back to 1922, specifically to two letters written by V.V. Bartold (dated August 6 and September 1) and a letter by A.Y. Krymsky dated August 19, 1922. This milestone was a turning point in the formation of the USSR and the birth of the Soviet Oriental studies.

Their correspondence is voluminous and covers a variety of social and professional issues. The scholars exchange information about salient events that had taken place. For instance, V.V. Bartold informs his colleague about the losses in the ranks of Russian Orientalists: "You are probably aware of the conditions of our life here, and of our recent losses: the death of young Arabist I.P. Kuzmin, who we hoped would become the first Russian expert in Arabic philosophy, and the almost simultaneous deaths of Turkologist and Osmanist V.D. Smirnov (1846-1922) and his young student P.A. Falev (1888-1922). For some time - I hope not for long - I.Y.

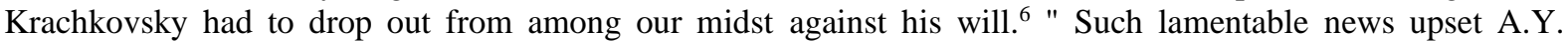
Krymsky: "I have eagerly read your reports about the life of St. Petersburg Orientalists. The deaths of Kuzmin, Falev, Smirnov - all those are news for me: sad, bitterly mournful news... Are there any more victims of death? The horror overwhelms me at the sight of this obituary. " "It was a reflection of the time that in 1922 A.Y. Krymsky did not immediately understand what the last phrase in V. V. Bartold's letter meant and asked him the following question: "You wrote: 'I.Y. Krachkovsky had to drop out from among our midst against his will'. What does it mean? Where is he?", and at the end of the letter he adds: "I would like to send my greetings to Krachkovsky by you, but from your letter I understand that he is not in Petersburg. I repeat my request, please let me know what has happened to him. ${ }^{8}$ " During the initial years of Soviet power, the persecution of dissidents had not yet become a common phenomenon in the life of society, and for this reason, news about the arrest of Arabist I.Y. Krachkovsky (1883 - 1951) blindsided A.Y. Krymsky. In the following letter V.V. Bartold was more specific: "I thought you would understand my 'descriptive' expression about Krachkovsky; now you probably already know from our newspapers, if they are reaching you, about numerous arrests among academics; Kr[achkovsky] is among them; although, as far as we know, he has always been very much distanced from politics. He has not yet been released; what he is accused of and what they intend to do with him is not yet known for certain. ${ }^{9} "$

Academician V.V. Bartold then informs his respondent about the innovations in the field of Orientalism in the capital and complains that any information about Oriental studies in Ukraine is reaching him with great difficulty. In particular, V.V. Bartold writes: "The first volume of a new journal called Vostok has just been 
published, founded by Vsemirnaya Literatura publishing house; it has sections titled 'Oriental studies', 'Bibliography' and 'Criticism'; and the 'Oriental studies' section has Krachkovsky's notes about the Czech Oriental Institute and some Polish publications on Oriental studies, but there is nothing about Ukrainian Oriental studies there [...] for the lack of information here about it. ${ }^{10}$ " In a response letter A.Y. Krymsky describes the state of affairs in Kiev, thanks to which we learn some new details about the formation and development of the Soviet Ukrainian center of Oriental studies. "The situation with Oriental studies in Kiev is as follows," A.Y. Krymsky writes. "In the spring of 1918 I founded the Institute of Oriental Languages with teaching purposes, which [...] after having been renamed several times, has finally acquired the longest name: Institute for Foreign Relations, with the Oriental and the Anglo-Saxon departments. The languages included in the Oriental Department are not only Arabic, Persian and Turkish, but also some Balkan languages: Romanian, Modern Greek, Bulgarian and Serbian... Arabic is taught by T.G. Kezma [...] of Nazareth. He graduated from the Kiev Ecc[lesiastical] Academy, he speaks very good Russian and has excellent knowledge of Class[ical] Arabic (many times better than those Arabs that] often travel to Russia)... Pers[ian] was not as lucky. The names are flashing like meteors: Mirza Jafar (from Lazar[evsky] Inst[itute]), F.P. Petrov (from SPb), P.N. Loziev (who is now with the Pers[ian] Department at the Lazar[evsky] Institute), but all of them cannot really get accustomed enough to stay here, so this year the Pers[ian] Department is vacant. Turkish was at first taught by V. Shcherbina (Russian Consul from Asia Minor), but then it was given to T.G. Kezma, who is fluent in Turkish but has a typical Arabic accent... I alternate in my teaching practice: one year I teach the History of the Sassanids, Mohammed and the Caliphate, another year - the History of Turkey; in both of the courses literature is given the predominant place. ${ }^{11}$ " In that period many Orientalists were already established scholars and teachers with several years of experience. For example, Taufik Gavrilovich Kezma (1882-1958) taught Eastern languages in Kiev starting from 1909. Together with Vladimir Shcherbina, he compiled a textbook of the Turkish language, and A.Y. Krymsky made translations of his Moscow lectures and books into Ukrainian. V.V. Bartold reacted very vividly to the information received from A. Y. Krymsky by writing the following in a reply letter: "I am very grateful to you for allowing me to publish what you tell us about Oriental studies in Kiev; I have selected only factual data and reported yesterday at the meeting of the Orien[tal] Dep[artment] of the Arch[aeological] Soc[iety]. ${ }^{12} "$

Orientalists eagerly shared their plans for the future with each other. V.V. Bartold told one of his colleagues: "It is assumed that several scholars, including me, will travel to the West, but whether or not these trips will actually take place, it is difficult to say. It will be even more difficult to decide whether, at least in 1923, the supposedly 'all-Russian scale' congress of Turkologists will take place ${ }^{13}$. In any case, the survivors from among us still continue their work as far as possible, and they do not intend to cease it. ${ }^{14}$ " Nevertheless, despite organizational and ideological difficulties, in the 1920s V.V. Bartold's research travel to several European centers did happen ${ }^{15}$.

In his letters A.Y. Krymsky never ceases to be interested in the possibility of obtaining new materials necessary for him to continue his research. He asks V.V. Bartold: "Has Volume VI of Ibn Miskawayh already come out? ${ }^{16}$ I desperately need it, and I can't get any information about it. ${ }^{17}$ " In a reply letter V. V. Bartold, who had ample information on the subject, wrote the following: "The VI volume of Ibn Miskawayh you are interested in has been published [...] twice already, in facsimile and in print; we do not have it either. ${ }^{18}$ " Later, in 1925, in "Zapiski istorichno-filologichnogo viddidu UAN" ("Notes of the historical-philological faculty of UAN"), A.Y. Krymsky's new work came out, entitled "Pers'kij teatr, zvidki vin uzyavsya i yak rozvivavs'" ("Persian theater, how it was formed and how it developed"), in which, by his own admission, he widely used the work of Ibn Miskawayh $^{19}$.

In several of their letters, the participants of the correspondence address a problem that continues to be relevant today - the problem of the use of the Ukrainian language in science. Bartold and Krymsky did not reach an understanding on this issue, instead agreeing to disagree. A.Y. Krymsky was known to have been not only a famous Orientalist, but also an outstanding Ukrainian linguist, writer and poet. His poetry collection "Pal'move gillya" (Palm tree branches) ${ }^{20}$ includes not only his own poems, but also his translations of poetry classics from around the world, including ones made from original poems written by Arab-Muslim authors. Its third part began with the "V Trapezunti" ("In Trebizond") poetry cycle, dedicated to the author's stay in 1917 in Trebizond, which was occupied by Tsarist troops. Together with well-known Byzantinist and collector of Oriental manuscripts F.I. Uspensky (1845-1928), A.Y. Krymsky was dispatched there by the Russian Academy of Sciences to describe and study ancient manuscripts stored in local monasteries and mosques.

In a letter dated August 6, 1922, V.V. Bartold thanked A.Y. Krymsky for the poetry collection he had sent him, but at the same time he expressed his own opinion about it: "Personally, I would find it more desirable if Ukrainian literature were limited to the field of dialectical poetry and if the language of Russian science was the one language that was developed, as we know, with the active participation of Ukrainians by birth; but, of course, I cannot convince you of this. In any case, it would seem that it is possible to write in Ukrainian without that hatred of anything Moscow-related that your book is imbued with [...] It is hardly necessary to prove, especially after your poetry pieces [...] that the army that was standing in Trebizond was not a Moscow army but 
an All-Russian one; there is also no evidence that the 'vandal' acts were committed solely by Russians; not to mention the fact that you were just one of many individuals sent there by the Academy, and not even the main person in the mission, and that the ancient monuments are to be protected not only from military operations but also from all other accidents. ${ }^{21} "$

It took A.Y. Krymsky some time to formulate his position on this burning issue. On August 19, 1922, he sent V.V. Bartold a message that was so remarkable that it has been quoted here almost in full, with only small redactions in the translation. "I have received your letter...", A.Y. Krymsky wrote, "and it has unspeakably saddened me. A reproach of hatred to all things Russian is a very harsh and offensive one for me, because I actually belong to those Ukrainians who struggle here, in Kiev, against any sort of enmity to Russians and Russian culture and get accused of 'Russophilia to the point of betrayal of one's own culture'. The generations that are younger than me were even ready to cross me out of the list of Ukrainians but, unfortunately for them, there were two serious circumstances against that, the first being that Krymsky cannot be simply crossed out of the history of Ukrainian literature in which he played not the least of roles by having contributed to it for thirty years, while the second is that Krymsky is a more natural Ukrainian than most new ones, and that these superpatriotic people are forced to acknowledge that Krymsky has a most respected place in terms of Ukrainian language competence and the mastery of its style in all its subtleties. In any case, I hear enough sour words about my 'Russification', and sometimes certain methods are adopted to get rid of me in the cases where I am deemed 'harmful' [...] The Academy of Sciences itself, where I am Secretary, is called 'Russifying', antipatriotic, etc. by a certain group of people [...] from the above facts, you could come to the conclusion that hostility to the Russian culture is alien to me. Instead, after reading my book you have concluded that I have a hatred for all things Russian! I am afraid, dear and respected Vasily Vladimirovich, that if all Russians, like you, treat Ukrainian literature with such prejudice, subtracting from each Ukrainian word what was never intended to be said, the result may indeed be that a gap will gape open between Ukrainians and Russians, w[hich] then will be very difficult to fill up [...] You write to me that my book is imbued (!) with hatred to Russian culture, and then you specify, saying that it is [...] particularly hateful on p. 8 [...] But I mention the 'Russian Academy of Sciences' as a cultural beacon that acts as a savior of cultural values. So why did you not want to pay attention to my emphasizing the merits of the 'Russian' Academy of Sciences? A Russophobe would never mention it [...]It is clear that a Ukrainian reader [...] will in no case find any anti-Russian antics in my poetic cycle "In Trebizond". As for non-Ukrainian readers, it is also clear: before making conclusions that are offensive for the author, they should have confidence that they have correctly understood the Ukrainian text. [...] I very rarely write letters, except short and dry ones, purely about business. But this time I have changed my custom, and I have answered your letter with an entire epistle. Sorry for the outburst [...] You think it would be better for Ukrainians to stick to the All-Russian language and confine themselves to the dialectical area [...] Of course, everybody is entitled to their own opinion: die gedanken sind zollfrei. But I assure you that your opinion is striking in its colossal incongruity with the facts of reality. When Ukrainian is a working language for 12 universities, when this language abundantly manifests itself in science, in social and political life, in legal relations, in legislation, administration, etc., thinking like you do means chercher midi a quatorze heures. So, without a shadow of chagrin, but only with amazement I have read your opinion..."22

V.V. Bartold's reply to A.Y. Krymsky's emotional message followed quickly enough: "...I do not deny the Ukrainian movement, only I do not approve of it, as well as of many other things in the course of history certainly, without imagining for a minute that the course of history will adapt to my tastes or that I can turn the wheel of history back with my own hand [...] you know, the Russian language, especially in science, is not substituted with the natural, vigorous Ukrainian of the 'working-class people' but with an artificial language that people have learned in an artificial way. There is nothing like this in any other country, nowhere, if I am not mistaken, does the common literary language not lose its once won positions. On the contrary, it usually expands the sphere of its domination more and more... None of us is quite aware of what is going on in Ukraine; it seems, no one here knew that 'Muscovite' now means 'Russian' in Ukrainian. [...] In human life, too, just as in the life of nature, next to the real movements there are imaginary ones. Which of them the Ukrainian movement belongs to, only time will tell. ${ }^{23} "$

Unfortunately, in the surviving letters of the two men there is no information about the further course of this heated discussion.

Five years after V.V. Bartold's death (1930) A.Y. Krymsky wrote the following in a letter to I.Y. Krachkovsky, who had sent him prints of his latest articles: "Bartold's obituary is extremely well-written. It was a surprise to me to see that writing about him and his merits is finally permissible ${ }^{24}$. Mentioning him here is a taboo. About three years ago I was invited to read an essay about him denouncing his bourgeois, counter-revolutionary activities, and we are not allowed to say anything other than that about him. Naturally, I refused this idiotic proposal; but I was then told that in St. Petersburg there is no academic wake for Bartold

due to his 'nasty' ideology. [...] You have characterized Bartold very vividly [...] Even the awkward heaviness of Bartold's style has been noted, albeit in a very 'academic' tone ${ }^{25 "}$. 
In their correspondence, V. V. Bartold and A. Y. Krymsky tried to keep each other informed of the current Oriental studies-related events in the USSR. V.V. Bartold informed A.Y. Krymsky: "In Tashkent, as A.E. Schmidt told me in a letter ${ }^{26}$, a summary of my lectures on the history of Turkestan, delivered in 1920, is soon going to be published. Things are not going well with Tashkent University, many people have left it; because of constant 'reform' experiments as well as for other reasons; Schmidt now feels quite lonely; he intends to travel to Moscow and here to petition before the centr[al] govern[ment]"27. In a response letter A.Y. Krymsky expressed his sincere admiration of the report that V.V. Bartold had sent him regarding his research trip to Turkestan: "Today I have received your report about your trip to Turkestan in 1920. You have no idea with what great interest, with what avidity I have read it. Everything in it was a revelation to me. I most sincerely thank you!"28. A.Y. Krymsky was also very much impressed by V.V. Bartold's lecture course "The place of the Caspian regions in the history of the Islamic world"29. "I was actually enjoying myself when I read it", A.Y. Krymsky wrote to the author. "The very form of its presentation, the lecture form, with questions from the listeners, not only did not weaken my interest, but, on the contrary, enhanced it, as if taking me directly into that lecture room, making me feel that I was sitting there among the curious listeners. I mentally pictured this audience before me, I vividly felt that Oriental studies in Russia cannot stall, despite all the heavy blows to it, and my soul was elevated by the gratifying feeling of communication between all of us. ${ }^{30}$ "

In the course of the correspondence A.Y. Krymsky retold V. V. Bartold all the details of his current research. In particular, he wrote: "A lot was done during my stay in Kiev, and since now I have an opportunity to print it, then my finished works will not lie around unpublished [...] The first chapters of my work on Hafez ${ }^{31}$, due to their appeal to a wider audience, have already been handed over to the printing works [...] a reprint will be made [...] of course, I will not hesitate to send it [...] It took me quite a lot of time to write the essay on the history of Persia of the 9 th -10 th centuries. ${ }^{32}$ For almost two years I have diligently checked all the Arabic sources line by line, so that the message of each fact was based on an accurate reference and so that not a single interesting cultural or lifestyle-related feature was [omitted]. ${ }^{33}$ "

In the letter, A.Y. Krymsky gives a brief description of the state of the Kiev library collections regarding Arabic and Iranian studies: "The situation with Oriental libraries is much more favorable than one might expect. First of all, a huge surprise for me was that the library of Kiev U[niversi]ty, for the ninety years of its existence, has acquired a far from poor selection of works and publications on the East. There are sets of Oriental studies journals (among them the complete JRAS ${ }^{34}$, whereas in the Lazar[evsky] Institute it only starts from the 1900 issues), there are Europ[ean] translations of works by historians and geographers (hence, most often of Orient[al] texts, for ex[ample] Masudi ${ }^{35}$ ), there are general works on Oriental literatures (including even the heavy Lit[eratur]gesch[ichte] der Araber by Hammer ${ }^{36}$ ). A colossal 'People's Library' has developed at the AllUkrain[ian] Academy of Sciences (approx. 1200000 vol.) and one of its departments is separate: Orientalia... It is a predominantly Jewish Department... Muslim books here are few, because they systematically arrive to my 'Research Center of Arabic-Iranian Philology'. It was based on my very large library donated by me to the Academy of Sciences... Moreover, it was discovered that in Kiev, and especially in the Kiev region, there were a number of quiet, unknown aficionados of Oriental languages; some of them have long since died. Their libraries [...] were also acquired for the 'Research Center of Ar[abic]-Ir[anian] Philology' [...] I can certainly be proud of the creation of such a library in Kiev [...] I console myself with the thought that sooner or later Kiev [...] will have to develop Oriental studies in full, and the academic library, which never ceases to be enriched by new inflows of books, will truly become very useful" 37 .

In 1926 V.V. Bartold completed a voluminous course of lectures on the history of the Turkic peoples, which he delivered to students of Istanbul University at the request of the Turkish government ${ }^{38}$. This is what he wrote in a letter to A.Y. Krymsky from Istanbul: "Lectures are delivered for a relatively large number of listeners, more than 20; [they] are devoted to the history of the Central Asian Turks; I wrote them in Russian, and then a Turkish translation was made by Validov ${ }^{39}$ and reviewed by me; in general, the translation seems to me very well done. The final lectures will be translated by local young Turkologist Raghib Hulusi, a linguist, who has recently arrived from Budapest, where he studied under Németh ${ }^{40}$ and received his doctorate. ${ }^{41}$ "

On his way back from Istanbul V.V. Bartold visited Kiev, but he was not able to get in touch with A.Y. Krymsky there. "My first impression of Kiev [...] is certainly a good one;" writes V.V. Bartold, "apparently, people here are trying to do what they can under rather difficult conditions, especially with regard to the premises; so, everyone will be struck by the extreme lack of space in the museum." Comparing Kiev to Istanbul, he wrote: "I am perhaps even more impressed by this crampedness and lack of space compared to Constantinople that I only just left, where accommodation conditions in educational institutions may be better than anywhere else, but where this vast amount of space is relatively little used due to the lack of trained people, both among teachers and employees, and among students and postgraduates. ${ }^{42}$ "

Starting from the mid-1920s A.Y. Krymsky described the Kiev academic environment to V.V. Bartold. "The atmosphere of academic life in Kiev becomes openly oppressive. Hrushevsky arrived ${ }^{43}$ and immediately began spreading toxic hatred around... I remember how you, thank you for your frankness, once accused me of having an aversion to the Russians. I told you back then that your words caused me a heavy heartache. And now I have 
to face systematic bullying from Hrushevsky [...] for [...] 'hostility to all things Ukrainian'. [...] In Kiev, he constantly verbally proclaims us traitors to our nation and tries to undermine even our right to be called Ukrainians, especially me, who has spent all his life in Moscow. ${ }^{44}$ "

A. Y. Krymsky had served as a secretary in the Ukrainian Academy of Sciences since its foundation in 1918. He wrote to V.V. Bartold: "I feel a burning need to get away from people, to hide in my office (as I did all my life), not to take any part in the local social life, to only mind my Oriental studies and nothing else, and not to give anyone a reason and a right to dig into my national or ethnic beliefs... an importunate question is nagging me with special force: 'But when, at last, will I be able to live and breathe only the interests of Oriental studies!'”45 However, in 1929, after the General Assembly of the Ukrainian Academy of Sciences once again re-elected A.Y. Krymsky academician-secretary, the authorities did not confirm his appointment. In a letter sent by him to V.V. Bartold on March 25, 1927 he wrote: "The closer I get to death, the more jealously Orientalism speaks in me, and sometimes for weeks I cannot shake off the thought that my life, in the end, did not turn out as my heart desired. Last May (of the year 1927) I decided, perhaps in a somewhat strange manner, to throw off my administrative duties in order to [...] withdraw into the four walls of my library. It was impossible for me to simply give up my secretarial duties because of all kinds of companionship or social relations, so I tried to arrange the matter so as to become an undesirable person for the ruling circles, who was supposed to be excluded from amongst the candidates to become the secretary in the future. [...] This will certainly affect my financial situation (as an academician, I get paid 180 rubles, but as a secretary I get 210), but I need so little for living that this question never bothers me, and, of course, I should value my salvation from the administrative yoke much higher than my secretary salary. I now live in the hope that at last, at the end of my life [...] I will be able to move away from all the fuss and at least complete my most important works, which I have worked hard over, and so far I have not had the opportunity to complete them because of the administrative serfdom [...] In my head I only see pictures of my future freedom, unlimited research work, without the bureaucracy - but this yoke that I have not yet thrown off my neck still remains as of now. This contrast makes me overstrain my nerves [...] I personally am absolutely not afraid of death, but what I am afraid of is having to live the last years of my life with the feeling that a lot has not been completed and, perhaps, will remain uncompleted - this feeling is burning me from inside. ${ }^{46}$ " This letter reads almost like a confession and indicates that A.Y. Krymsky often shared his innermost thoughts with V.V. Bartold, thoughts that were not intended for anybody else.

The final part of the correspondence between the two luminaries of Russian and Ukrainian Oriental science mostly concerned the circumstances of their personal life and academic subjects. In 1928, after the death of his wife Maria Alekseevna, V. V. Bartold received from A.Y. Krymsky a letter of condolence, imbued with sincere sympathy and concern for the state of his colleague after his loss. In the same letter A.Y. Krymsky mentions a collection of articles he had received that was dedicated to V.V. Bartold by his Turkestani friends and colleagues ${ }^{47}$. He also reports that together with I.Y. Krachkovsky he was ready to organize a similar publication in honor of the upcoming birthday of V.V. Bartold (he turned 60 in 1929).

In a response letter V.V. Bartold thanks his colleague for his support at this difficult time (in his own words, he had "returned to normal work in less than a week after the death" of his wife) and adds: "The collection presented to me by the Turkestani colleagues made me and especially my late wife very happy [...] We both thought that having a collection like this dedicated to you is much nicer than those kind of formulaic collections that are usually devoted to scholars of 'global renown' (who I never considered myself to be)"48. And that is why he asks A.Y. Krymsky to abandon the idea of publishing a collection in his honor, and at the end of the letter he returns to the subject of the state of academic affairs. "I have heard amazing rumors about the 'audit' of the Ukrainian Academy," V.V. Bartold writes ${ }^{49}$. In 1930, a radical restructuring began in the Academy of Sciences of the USSR: a new charter was adopted, which effectively made all academic work subordinate to the interests of the Soviet state. V.V. Bartold did not live to see this happen. He died on August 19, 1930. This was the beginning of a dramatic chronicle in the history of Soviet Oriental studies of the 1930s.

\section{CONCLUSION}

Eminent scholars and professors V.V. Bartold and A.Y. Krymsky were brought together by their shared professional and human interests. These brilliant researchers of the Eastern world could not be separated by any differences in views on social and political processes because they were primarily interested in the science of the East. The epistolary legacy of A.Y. Bartold and A.Y. Krymsky preserves the warmth that existed in the relationship of these respected representatives of Oriental studies and remains a significant factor in the history of the Oriental science in Russia, Ukraine and Europe.

The epistolary legacy of A.Y. Y. Krymsky, especially as regards his correspondence with Russian Orientalists, is important for contemporaries. Firstly, the correspondence is a collection of handwritten documents from the most prominent Russian Orientalists of the 19th - early 20th centuries. Secondly, these letters present the personal views of two high-profile scholars and outstanding individuals. Thirdly, the documents reveal a unique assessment of the state of Oriental studies at that time, specifically in the Arabian, Iranian and Turkic fields of research and the roles of leading Russian academicians and thinkers. Fourthly, the letters convey the personal 
opinions and sentiments of these men and scholars particularly sharply. On the whole, the content of the correspondence can serve as original material for the academic biographies of outstanding Orientalists and the history of Russian and European Oriental studies of the 19th - early 20th centuries.

The correspondence of these well-known Orientalist scholars, not yet introduced into scientific circulation, is the object of research within the framework of a scientific project whose goal is to study, systematize and prepare for publication the previously unknown epistolary legacy of Orientalists in Russia, Ukraine and Europe who worked at the turn of the 19th-20th centuries, and specifically research work with the correspondence of A. Y. Krymsky with V. R. Rosen, F.E. Korsch, V.A. Zhukovsky, S.F. Oldenburg, V.V. Bartold, N.A. Mednikov, P.K. Kokovtsov, B.V. Miller, V.F. Minorsky, and others.

\section{ACKNOWLEDGEMENTS}

The work has been performed under the Russian Government Program of Competitive Growth of Kazan Federal University, RFBR project № 20-09-00385 A.

\section{REFERENCES}

1. Bartold, V. [review for] N.A. Aristov. Zametki ob etnicheskom sostave tyurkskih plemen i narodnostej i svedeniya ob ih chislennosti [Notes on the ethnic composition of Turkic tribes and nationalities and information about their numbers]. - Saint Petersburg, 1897 // Zapiski Vostochnogo otdeleniya Russkogo arheologicheskogo obshchestva [Notes of the Eastern branch of the Russian Archaeological Society]. 1897. Vol. XI. - Saint Petersburg, 1899. - P. 355.

2. Bartold, V.V. Sochineniya [Works]. In 9 volumes. Moscow, 1963-77; Bartold, V.V. Istoriya izucheniya Vostoka v Evrope i Rossii [The history of researching the East in Europe and Russia]. Leningrad,1925; Lunin, B.V. Zhizn' i deyatel'nost' akademika V. V. Bartol'da: Srednyaya Aziya v otechestvennom. vostokovedenii [The life and works of academician V. V. Bartold: Central Asia in the Russian Oriental studies]. Tashkent, 1981; Istoriya otechestvennogo vostokovedeniya s serediny XIX veka do 1917 goda [The history of Oriental studies in Russia from mid-19th century to 1917]. Moscow, 1997; Tolz Vera. Russia's Own Orient: The Politics of Identity and Oriental Studies in the Late Imperial and Early Soviet Periods. Oxford., 2011; Kemper M. "Red Orientalism: Mikhail Pavlovich and Marxist Oriental Studies in Early Soviet Russia” // Die Welt des Islams 50 (2010). P. 435-476; Schimmelpenninck van der Oye David. Russian Orientalism: Asia in the Russian Mind from Peter the Great to the Emigration. New Haven \& London, 2010, etc.

3. Gurnitsky, K.I. Agafangel Efimovich Krymskij [Ahatanhel Yukhymovich Krymsky]. Moscow, 1980; Krymsky, A.Y. Vibrani skhodoznavchi praci: v 5 t. [Selected Oriental works: in 5 volumes] Vol. I. Arabistika [Arab studies]. Kiev, 2007; Krymsky, A.Y. Vibrani skhodoznavchi praci: v 5 t. [Selected Oriental works: in 5 volumes] Vol. IV. Iranistika [Iranian studies]. Kiev, 2008; Krymsky, A.Y. Vibrani skhodoznavchi praci: v 5 t. [Selected Oriental works: in 5 volumes] Vol. V. Iranistika [Iranian studies]. Kiev, 2010; Ahatanhel Krymsky. Narisi zhittya i tvorchosti [Ahatanhel Krymsky. Essays on life and work]. Kiev: 2006; Epistolyarna spadshchina Agatangela Krim'skogo v 2-h tomah [The epistolary recession of Ahatanhel Krymsky in 2 volumes.] Vol. 1. (1890 - 1917). Vol. II (1918 - 1941). Kiev, 2005, etc.

4. Perepiska akademikov A.E. Krymskogo i I.Y. Krachkovskogo 1920-1930-h godov [Correspondence between academicians A.Y. Krymsky and I.Y. Krachkovsky in 1920-1930] / published by I.M. Smilyanskaya // Neizvestnye stranicy otechestvennogo vostokovedeniya [Unknown pages of Oriental studies in Russia]. - Moscow, 1997. - P. 198.

5. Krachkovsky, I. Akademik AN USSR A. E. Krymskij (K 70- letiyu so dnya rozhdeniya)[Academician of the Academy of Sciences of USSR A.Y. Krymsky (dedicated to the 200th anniversary of his birth)] // Izevstiya AN SSSR. Dept. of Literature and Language. No 1. Moscow, 1941. P. 129.

6. Tumanovich, N.N. Opisanie arhiva akademika V. V. Bartol'da [Description of academician V.V. Bartold's archive]. - Moscow, 1976. - P. 232.

7. Institute of Manuscripts of the V.I. Vernadsky National Library of Ukraine (hereinafter - IM VNLU), f. I, d. 22666, 1. 2 reverse.

8. St. Petersburg branch of the Archive of the Russian Academy of Sciences Archive (hereinafter SPb ARAN), f. 68, op. 2, d. 128, 1. 9.

9. SPb ARAN, f. 68, op. 2, d. 128, 1. 9-10. 
10. IM VNLU, f. I, d. 22667, 1. 3. July 22, 1922 I.Y. Krachkovsky was arrested by the State Political Directorate (GPU) under the NKVD of the RSFSR (he carried out his activities in 1922 - 1923) on a fictitious charge of espionage in favor of Finland and placed in solitary confinement. Only persistent petitions from the Academy of Sciences and Krachkovsky's colleagues saved his life (he was released on January 12,1923). While in custody, as soon as he was allowed to use special literature, he continued his translation of the Quran and his other research. After his release, I.Y. Krachkovsky was under the supervision of the GPU, and from June 12, 1923, a struggle began against his planned expulsion to Kazan for a three-year term (the exile was eventually canceled) (see more: Lyudi i sud'by. Biobibliograficheskij slovar' vostokovedov - zhertv politicheskogo terrora v sovetskij period (1917-1991) [People and destinies. Bibliographical dictionary of orientalists who were victims of political terror in the Soviet period (1917-1991). - SPb., 2003. P. 220-221; "Ego otsutstvie budet bedstviem". Pis'ma v zashchitu repressirovannyh: Iz sledstvennogo dela I.YU. Krachkovskogo ["His absence will be a calamity". Letters in defense of the repressed: From I.Y. Krachkovsky's investigation file]. // Istochnik. 1998. No 2. P. 51-56. On the circumstances of the arrest, see: Dolinina, A.A. Nevol'nik dolga [The prisoner of duty]. - $\mathrm{SPb}$, 1994. P. 166-17. From the latter work we learn that even after 1925 Soviet authorities prohibited I.Y. Krachkovsky from traveling abroad to academic forums.

11. IM VNLU, f. I, d. 22666, 1. 1.

12. SPb ARAN, f. 68 , op. 2, d. 128, 1. 11-11 reverse.

13. IM VNLU, f. I, d. 22667, 1. 2.

14. The first All-Union Turkological Congress was held in Baku in February of 1926. One of the main tasks of the Congress was to develop a new Turkic alphabet. It also addressed the issues of scientific terminology, orthography of Turkic peoples and methods of teaching Turkic languages. V.V. Bartold and A.Y. Krymsky took part in this work, which gave them an opportunity to communicate in person. V.V. Bartold was also involved in the preparation of this noteworthy event and prepared a report on "the current state and the immediate tasks of studying the history of the Turkic peoples".

15. IM VNLU, f. I, d. 22666, 1.2 reverse.

16. In 1922-1923 V. V. Bartold made research trips to Finland, England, Belgium, the Netherlands and Germany; in 1923 he was a delegate from the Russian Academy of Sciences at the International Congress of historians in Brussels; in London he lectured on the history of the Turks and Mongols; in 1926 in Istanbul at the invitation of the Turkish government he lectured on the history and culture of the Turkic peoples (in 1927 these lectures were published in Turkish; in 1935 - in German; in 1945 - in French). In 1929 he actively worked in manuscript centers of Berlin, Hamburg and Göttingen.

17. Ibn Miskawayh, Abu Ali Ahmad Ibn Muhammad (d. in 1030) was an Arabic-language historian, author of the treatise "Tajarib al-umum wa awakib al-himam" ("Experiences of nations and consequences of aspirations") (written in the late 980s).

18. SPb ARAN, f. 68, op. 2, d. 128, 1. 11.

19. IM VNLU, f. I, d. 22667, 1. 17.

20. Tsigankova, E. Skhodoznavchi ustanovi v Ukraini. Radyans'kij period [Orient studies institutions in Ukraine. Soviet period]. - Kiev, 2007.

21. The first part of this collection was published in 1901 in Lviv, the second one - in 1908 in Moscow, and the third part was printed in Kiev in 1922.

22. IM VNLU, f. I, d. 22666, 1. 1-2.

23. SPb ARAN, f. 68 , op. 2, d. 128, 1. 3-9.

24. IM VNLU, f. I, d. 22667, 1. 1-1reverse.

25. The first obituary on the death of V.V. Bartold was published by I.Y. Krachkovsky immediately after Bartold's death in the evening edition of "Krasnaya gazeta" dated August 21, 1930.

26. Perepiska akademikov A.E. Krymskogo i I.YU. Krachkovskogo 1920-1930-h godov. Publikaciya I.M. Smilyanskoj [Correspondence between academicians A.Y. Krymsky and I.Y. Krachkovsky of the 1920s and 1930s. Publication by I.M. Smilyanskaya // Neizvestnye stranicy otechestvennogo vostokovedeniya [Unknown pages of Oriental studies in Russia]. - Moscow, 1997. P. 219.

27. Alexander Eduardovich Schmidt (1871-1939) was a Russian Arabist and Islamic scholar. In 1897 he trained in European scientific centers under Ignác Goldziher, Michael de Goeje and Joseph von Karabacek and worked in various Oriental manuscript centers of Europe. 
28. IM VNLU, f. I, d. 22667, 1. 4 .

29. SPb ARAN, f. 68, op. 2, d. 128, 1. 13.

30. Bartold, V.V. Mesto Prikaspijskih oblastej v istorii musul'manskogo mira (kurs lekcij) [The place of the Caspian regions in the history of the Islamic world (lectures)]. - Baku, 1924.

31. SPb ARAN, f. 68, op. 2, d. 128, 1. 14 .

32. Krymsky, A. Hafiz ta jogo pisni (bl. 1300-89) v jogo ridnij Persiï XVI v. ta v novij Evropi [Hafez and his poetry (c. 1300-89) in his native Persia of the 16th century and in modern Europe]. - Kiev, 1924.

33. Krymsky, A. Istoriya Persiï ta iii pis'menstva [History of Persia and its written heritage]. Vol. 1. Yak Persiya, zvojovana arabami, vidrodilasya politichno (IX ta X vv.) [How Persia, conquered by Arabs, re-emerged as a political force (9th to 10th centuries). - Kiev, 1923.

34. SPb ARAN, f. 68, op. 2, d. 128, 1. 7-8.

35. The Journal of the Royal Asiatic Society of Great Britain and Ireland, published in London since 1834.

36. Al-Masudi, Abu-1-Hasan Ali Ibn al-Hussein (d. in 956) was an outstanding Arab-Muslim historian, geographer and traveller.

37. Hammer-Purgstall, Joseph von. Literaturgeschichte der Araber von ihrem Beginne bis zum Ende des zwölften Jahrhunderts der Hịdschret. Bd. 1-7. - Wien, 1850-1856.

38. SPb ARAN, f. 68, op. 2, d. 128, 1. 9-10. Ukrainian scholar A.Y. Krymsky keeps his Russian counterpart informed of all the changes in his professional activities related to the increase in his teaching load. "The government is straining me into a stronger pedagogical activity", - he tells V.V. Bartold, "than that in which I was working before now. A research department of 'Linguistics' has been created in Kiev, and I have been forced to take charge of it. At the same time, I have been instructed to take the three so-called 'graduate students' (i.e. professorial fellows) into my own hands and pass my linguistic knowledge on to them[...]So this is where things stand with training Orientalists." (SPb ARAN, f. 68, op. 2, d. 128. 1.9).

39. See: Bartold, V.V. Otchet o komandirovke v Turciyu [Report on a research trip to Turkey] // Izvestia AN. 1926. Ser. VI. Vol. XX. P. 832-834 (Annex to the minutes of the meeting of the Department of History and Philology of the USSR Academy of Sciences dated 10/29/1926).

40. Validov (Validi) Akhmet-Zaki (1890-1970) was a Tatar-Bashkir historian, orientalist, journalist and politician.

41. Gyula Németh (1890-1976) was a Hungarian orientalist, Turkologist, and Professor of Turkic philology of Budapest University in 1916-1964.

42. IM VNLU, f. I, d. 22669, 1.1 reverse.

43. IM VNLU, f. I, d. 22670, 1.1 reverse.

44. Hrushevsky, Mykhailo Serhiyovych (1866-1934) was a Ukrainian historian who specialized in the history of Ukraine and Ukrainian literature. From 1919 to 1924

45. he lived in Austria as an immigrant.

46. SPb ARAN, f. 68 , op. 2, d. 128, 1. 14 .

47. SPb ARAN, f. 68, op. 2, d. $128,1.14$ reverse.

48. SPb ARAN, f. 68, op. 2, d. 128, 1. 19-21.

49. V.V. Bartol'du turkestanskie druz'ya, ucheniki i pochitateli [To V.V. Bartold from his Turkestani friends, students and admirers] / Ed. by A.E. Schmidt and E.K. Betger. Tashkent, 1927. In the introduction to this collection its authors wrote the following: "Dear Vasily Vladimirovich! By defending your thesis 'Turkestan in the era of the Mongol invasion' 25 years ago, on December 2, 1900, you laid a solid foundation for the strictly scientific, source-based studies of Central Asia.[...]Your works, which, for the first time in Turkestan, were carried out fully armed with the European scientific method, constituted an entire epoch in the studies of the past of Central Asia..." (p. X).

50. Institute of Manuscripts of the V.I. Vernadsky National Library of Ukraine (IM VNLU), f. I, d. 22664-22671 [Letters from V.V. Bartold to A.Y. Krymsky].

51. St. Petersburg branch of the Archive of the Russian Academy of Sciences (SPb ARAN), f. 68, op. 2, d. 128 [Letters from A.Y. Krymsky to V.V. Bartold].

52. Bartold, V.V. Mesto Prikaspijskih oblastej v istorii musul'manskogo mira (kurs lekcij) [The place of the Caspian regions in the history of the Islamic world (lectures)]. Baku, 1924. 
53. Bartold, V.V. Otchet o komandirovke v Turciyu [Report on a research trip to Turkey] // Izvestia AN. 1926. Ser. VI. Vol. XX. P. 832-834.

54. V.V. Bartol'du turkestanskie druz'ya, ucheniki i pochitateli [To V.V. Bartold from his Turkestani friends, students and admirers] / Ed. by A.E. Schmidt and E.K. Betger. Tashkent, 1927.

55. Valeev, R.M.; Vasilyuk, O.D.; Kirillina, S.A.; Meyer, M.S. Iz zhizni otechestvennogo vostokovednogo soobshchestva na zare XX stoletiya: perepiska V.V. Bartol'da i A.E. Krymskogo v 1908-1913 gg. (po materialam arhivnyh fondov) [The life of the Russian Oriental studies community at the dawn of the 20th century: correspondence between V.V. Bartold and A.Y. Krymsky in 1908-1913 (based on archival materials)] // Vestnik Moskovskogo universiteta. Ser. 13. Oriental studies. 2018. No 4. P. 3-18.

56. Dolinina, A.A. Nevol'nik dolga [The prisoner of duty]. - SPb, 1994.

57. "Ego otsutstvie budet bedstviem". Pis'ma v zashchitu repressirovannyh: Iz sledstvennogo dela I.YU. Krachkovskogo ["His absence will be a calamity". Letters in defense of the repressed: From I.Y. Krachkovsky's investigation file]. / I Istochnik. 1998. No 2. P. 51-56.

58. Epistolyarna spadshchina Agatangela Krims'kogo (1890-1941 rr.). T. II (1918-1941 rr.) [Epistolary legacy of Ahatangel Krymsky (1890-1941). Vol. II (1918-1941). Kiev, 2005.

59. Krymsky, A. Istoriya Persiï ta iii pis'menstva. T. 1. Yak Persiya, zvojovana arabami, vidrodilasya politichno (IX ta X vv.) [History of Persia and its written heritage. Vol. 1. How Persia, conquered by Arabs, re-emerged as a political force (9th to 10th centuries)]. - Kiev, 1923.

60. Krymsky, A. Pers'ky teatr, zvidky vin uzyavs' i yak rozvyvavs' [Persian Theater, Its Development and Origins]. - Kiev, 1925.

61. Lyudi i sud'by. Biobibliograficheskij slovar' vostokovedov - zhertv politicheskogo terrora $\mathrm{v}$ sovetskij period (1917-1991) [People and destinies. Bibliographical dictionary of orientalists who were victims of political terror in the Soviet period (1917-1991)] / content by: Y.V. Vasilkov, M.Y. Sorokina. SPb., 2003.

62. Krymsky, A. Hafiz ta jogo pisni (bl. 1300-89) v jogo ridnij Persii XVI v. ta v novij Evropi [Hafez and his poetry (c. 1300-89) in his native Persia of the 16th century and in modern Europe]. - Kiev, 1924.

63. Perepiska akademikov A.E. Krymskogo i I.YU. Krachkovskogo 1920-1930-h godov. (Publikaciya I.M. Smilyanskoj] [Correspondence between academicians A.Y. Krymsky and I.Y. Krachkovsky of the 1920s and 1930s. (Publication by I.M. Smilyanskaya)] // Neizvestnye stranicy otechestvennogo vostokovedeniya [Unknown pages of Oriental studies in Russia]. - Moscow, 1997. P. 155-368.

64. Tsigankova, E. Skhodoznavchi ustanovi v Ukraini. Radyans'kij period [Orient studies institutions in Ukraine. Soviet period]. - Kiev, 2007.

65. Hammer-Purgstall, Joseph von. Literaturgeschichte der Araber von ihrem Beginne bis zum Ende des zwölften Jahrhunderts der Hịdschret. Bd. 1-7. - Wien, 1850-1856. 